\title{
Applications of Microfluidization and High Pressure Processing in Food Industry and the Effect of Them on Food Products
}

\author{
Vidana Gamage Gayan Chandrajith*, Dilukshi Vichakshana Karunasena, Roshima Vithanage \\ Department of Food Science and Technology, University of Sri Jayewardenepura, Gangodawila, Nugegoda, Sri Lanka \\ Email: ‘ga yanchandrajith1993@gmail.com, dilukshikarunasena@gmail.com
}

How to cite this paper: Gayan Chandrajith, V.G., Karunasena, D.V. and Vithanage, R. (2019) Applications of Microfluidization and High Pressure Processing in Food Industry and the Effect of Them on Food Products. Food and Nutrition Sciences, 10, 403-411.

https://doi.org/10.4236/fns.2019.104030

Received: March 11, 2019

Accepted: April 16, 2019

Published: April 19, 2019

Copyright $\odot 2019$ by author(s) and Scientific Research Publishing Inc. This work is licensed under the Creative Commons Attribution International License (CC BY 4.0).

http://creativecommons.org/licenses/by/4.0/

\begin{abstract}
With the development of technology, several new processing techniques are being introduced for the food industry. By applying those novel techniques to food systems, it has been found that the structural and functional properties of food could be altered. Microfluidization which is also known as high pressure homogenization is one of the novel technologies that could be applied in food industry to obtain many beneficial outcomes. High pressure processing is another novel technique that is mainly playing the microbicidal effect. This work is concerned on the possibility of using microfluidization and high pressure processing in food industry based on the experimental findings. These techniques could be used as useful tools in the field of food science and technology.
\end{abstract}

\section{Keywords}

Functional Properties, Food Industry, Food Molecules, High Pressure Processing, Microfluidization

\section{Microfluidization}

Microfluidization is a high-pressure homogenization technique in which the food sample is pressurized and modified as a result of high shear rate and impact forces [1]. Microfluidization is a unique technique applying high-pressure homogenization to product streams [2]. In this method, the sample is pressurized and passed through two geometrically identical micro channels and then two streams are collided with each other at very high velocities resulting in deformation and breakage of structures of food particles [2]. At present, the application of microfluidization in food research and development is gaining much atten- 
tion. Its application in food research proved that the reduction of particle size of food materials can not only alter their structure, surface area but also improve their functional properties [3].

\subsection{Microfluidization for Milling}

Microfluidization could be applied in the food industry for many purposes. Application in milling process is one of the applications of microfluidization. In a previous research, it was found that micro fluidization can be used as a milling technique and it has been used to produce gluten free bread formulation with corn gluten meal or zein. Microfluidization can produce the proper structure by decreasing particle size, building network structure, increasing surface area, and water holding capacity of zein through its modification effects. The addition of xanthan and citrus fiber to the formulation could further enhance the final quality of the bread [4]. Wet grinding combined with microfluidization has shown good potential to produce wheat bran-based beverages. Microfluidization treatment was beneficial for the stability of aleurone and peeled bran. Microfluidization could provide a better homogenisation of the particles thus increasing the viscosity and stability of the dispersions [5].

\subsection{Microfluidization for Encapsulation}

Microfluidization could also be applied in encapsulation technique. It could be used to improve the functional properties of encapsulated products. A previous study states that microfluidization could enhance the antimicrobial activity of lemongrass essential oil alginate nano emulsions against $E$. coli. Micro fluidization was able to reduce the particle size, dissolution capacity, and the hygroscopicity of encapsules made to be spray drying [6]. Micro fluidization could be used to produce palm oil-based nano-emulsion to encapsulate curcumin which has outstanding anti-inflammatory and anti-cancer medicinal properties but a poor bioavailability. Microfluidizer with the aid of Response Surface Methodology is capable to produce palm oil-based oil in water nano-emulsion encapsulating curcumin with small droplet size using low surfactant concentration and under optimum energy consumption [7]. Microfluidization could be used to produce fish oil emulsion with mesquite gum by Nanoemulsions. With optimum conditions an average droplet size around $200 \mathrm{~nm}$ could be taken to improve their absorption in the digestive tract. Fish oil contains poly unsaturated fatty acids which are health beneficial [8]. Micro fluidization could be used to alter the length of whey protein fibrils resulting reduced turbidity and viscosity of whey protein incorporated beverages [9].

\subsection{Microfluidization in Dairy Industry}

There is a possibility of applying micro fluidization in dairy industry. High-pressure technology has been used in the food industry to change the physical conformation of whey proteins by applying high hydrostatic pressures to protein solutions 
[10]. Yoghurt like product could be produced by microfluidizing the slurry of hazelnut without adding any additional ingredient such as milk powder or a hydrocolides [11]. The microfluidization process could be applied to increase solubility of dried whey products containing heated whey proteins. Microfluidization disrupted the heat-induced whey protein aggregates into non-sedimenting whey protein polymers [12]. High-pressure microfluidization could also be used as an alternative to conventional homogenization. High-pressure microfluidization of heat-treated milk was more effective than conventional homogenization in delivering desirable texture in low-fat yoghurt, showing significant improvements in viscosity, creaminess and texture attributes. Therefore, microfluidization has the potential for producing high-quality reduced-fat yoghurts [13]. Microfluidization could be applied to cheese milk to produce high quality cheese. Microfluidization of cheese milk and separate microfluidization of cream produced Cheddar cheese with a whiter color and increased cheese yield. However, cheese composition and texture was modified significantly by the treatment. Cheeses made from microfluidized cream were higher in moisture and had a softer texture. However, microfluidization of cheese milk at low pressure (7 MPa) could be recommended for production of good quality Cheddar cheese with higher yield [14].

\subsection{Microfluidization for Nutritional and Sensory Enhancement}

Microfluidization could be applied to improve the nutritional quality of soy protein isolates. Micro fluidization pre-treatment could be used to enhance the pancreatic hydrolysis pattern of soy protein isolate and on emulsifying capabilities of its hydrolysates at around $120 \mathrm{MPa}$. Some protein subunits that were resistant to pancreatin hydrolysis, became more readily hydrolysed by microfluidization [15]. Another work confirmed that the microfluidization led to transformation of insoluble aggregates of soy protein isolates into soluble ones, in which SH/SS interchanges might be involved. Therefore, findings suggest that the microfluidization treatment alone, or in combination with a thermal pretreatment, would be an effective technique to improve surface properties of soy protein isolates [16].

Microfluidization treatments could be used to effectively improve the functionalities of insoluble dietary fiber, which might be a potential fiber-rich ingredient in functional foods. High pressure microfluidization could reduce the particle sizes of peach and oat insoluble dietary fiber to submicron scale and it also triggered the redistribution of the fiber composition from insoluble dietary fiber to soluble dietary fiber. Microfluidized insoluble dietary fiber has shown higher water holding capacity, swelling capacity and oil holding capacity. Micro fluidized insoluble dietary fiber also could reduce the lipid absorption to body [17].

Microfluidization aids to improve the nutritional and sensory qualities of beverages, sauses and ketchup like products. It was used to apply to improve the nutritional and sensory qualities of Ottoman Strawberry juice. It could significantly increase the antioxidant capacity and total phenolic content, at a pressure 
of $100 \mathrm{MPa}$. The color values changes with increasing both pressures and pass number. In fact no undesirable brown color formation was recorded after microfluidization. The increase in temperature at higher pressures and pass numbers were identified as the most influential factors on the quality of the juice. Therefore, microfluidization at pressures up to $100 \mathrm{MPa}$ with a controlled cooling system is recommended for juice production with the desired quality [18] Microfluidization could be used to improve the physical and functional properties of tomato ketchups. Increased microfluidization pressures have resulted some improvements in serum viscosity and lycopene content of the ketchup samples. Pressure values around 1600 bars could result extremely small fibers and fibrils [19].

\subsection{Microfluidization in Extraction}

Micro fluidization could be applied as an extraction aid in food industry and to optimize extractions of different compounds from food systems. Dynamic high pressure micro fluidization assisted extraction was employed to extract polysaccharides from the fruit bodies of Lentinus edodes. It has significantly enhanced the yield of lentinan and exhibited stronger antioxidant capacity compared to the hot water extraction [20] [21]. Microfluidization assisted extraction could also be considered as a potential method for preparing sweet potato leaves flavonoid with higher antioxidant activity.

\section{High Pressure Processing}

High pressure processing (HPP) is a non-thermal processing technology that has been proven for food preservation with little effect on nutritional and sensory qualities [22]. In high pressure processing the pressure is transmitted using a fluid usually water as the medium to cause molecular structural changes in food molecules like proteins and polysaccharides and has been used to inactivate microorganisms in different kinds of food products.

\subsection{High Pressure Processing in Dairy Industry}

One of its applications is in dairy industry. To destroy harmful microorganisms in milk, commercially high temperature short time (HTST) systems are usually operated over $75^{\circ} \mathrm{C}$ and hold times of 18 seconds [23]. But, when the temperature of the heat treatment increases, changes may occur in the dairy product quality related to color, flavor, and protein stability [24]. Therefore, High pressure processing could be considered as an alternative mechanism to produce high-quality, safe, dairy products by eliminating pathogens and reducing spoilage micro flora [25]. High-pressure processing can be operated as a batch or continuous process. High hydrostatic pressure which is a batch process, has been used to eliminate dairy pathogens such as Escherichia coli [26] Listeria monocytogenes [27] and Staphylococcus aureus [28]. High pressure processing can alter the fat droplet size in milk and the make a fine emulsion of fat and protein thus 
can alter the final quality of dairy products.

\subsection{High Pressure Processing for Sterilization}

High pressure processing is considered as an attractive 'clean' technology having the ability to inactivate micro-organisms and denature undesirable enzymes. Therefore, high pressure processing has involved in the food industry to extend the shelf life of many foods, including processed meat products [29]. High pressure processing was able to substantially decrease the shear force and improved consumer eating attributes of the final meat product produced from pre-rigor longissimus thoracis (strip loin) from prime and bull animals [30]. High pressure processing at a pressure of $300 \mathrm{MPa}$, was able to effectively inhibit the occurrence of rigor and improve the tenderness of the pork loin. Due to high pressure processing minor reduction in calpain activity and a sharp decrease in calpastatin activity was observed in pork [31].

\subsection{High Pressure Processing for Improving Product Quality}

High pressure treatment at $200 \mathrm{MPa}$ for 10 minutes was found to be efficient to reduce rancidity in brown rice during storage, leading to large economic benefits. High pressure treatment at $400 \mathrm{MPa}$ for a very short time period has shown the lowest moisture content and enhancement of fatty acids during storage compared to untreated samples [32].

High pressure processing can be used for the preparation of starch films. It was found that the application of high pressure processing improved the physical properties such as high tensile strength and water resistance of starch films made by Buckwheat starch and tapioca starch [33].

High pressure processing could be applied in spice industry. High pressure treatment combined with a mild temperature treatment could enhance the microbial reduction after processing and microbiological stability during storage of fermented minced pepper and fermented minced pepper produced with high pressure treatment had better sensory qualities compared to heat treated samples [34].

The results of a study showed that it is possible to produce meager (Argyrosomus regius) hams with good textural properties and to reduce the microbial transglutaminase content using high pressure processing, as an alternative to the heat-induced gelation [35].

High pressure processing could be applied to fruit purees to extend their shelf life without damaging the bio active compounds in the fruit. The results of a study showed that high pressure processing is effective in extending the microbial shelf-life, maintaining the quality and preserving the bioactive antioxidants of Aronia berry puree during 8 weeks of refrigerated storage [36].

\subsection{High Pressure Processing in Bakery Industry}

High pressure processing could be applied in cake manufacturing to process the 
cake batter. It has been found that High pressure processing decreased molds and yeast and aerobic mesophilic bacteria counts batters. But cakes made by high pressure treated batter presented a lower volume, darker crust, and harder texture than cakes from untreated batters. Therefore, further research should be done on this [37].

\section{Conclusion}

According to the researches carried out on application of micro fluidization and high pressure processing in different purposes in food industry, it can be concluded that micro fluidization and high pressure processing are two best novel techniques that were introduced to food industry. Those techniques could be sometimes applied for milling purposes, extraction purpose, encapsulation purposes and sterilizing purposes and many more applications are there. Therefore, it could be stated that microfluidization and high pressure processing are multipurpose tools in the field of food science.

\section{Conflicts of Interest}

The authors declare no conflicts of interest regarding the publication of this paper.

\section{References}

[1] Cikrikci, S., Demirkesen, I. and Mert, B. (2016) Production of Hazelnut Skin Fibres and Utilisation in a Model Bakery Product. Quality Assurance and Safety of Crops \& Foods, 8, 195-206. https://doi.org/10.3920/QAS2015.0587

[2] Lagoueyte, N. and Paquin, P. (1998) Effects of Microfluidization on the Functional Properties of Xanthan Gum. Food Hydrocolloids, 12, 365-371.

https://doi.org/10.1016/S0268-005X(98)00004-6

[3] Ogawa, S., Decker, E.A. and McClements, D.J. (2003) Production and Characterization of O/W Emulsions Containing Cationic Droplets Stabilized by Lecithin-Chitosan Membranes. Journal of Agricultural and Food Chemistry, 51, 2806-2812. https://doi.org/10.1021/jf020590f

[4] Ozturk, O.K. and Mert, B. (2018) The Use of Microfluidization for the Production of Xanthan and Citrus Fiber-Based Gluten-Free Corn Breads. LWT-Food Science and Technology, 96, 34-41. https://doi.org/10.1016/j.lwt.2018.05.025

[5] Natalia, R.S., Juhani, S., Panu, L. and Kaisa, P. (2015) Wet Grinding and Microfluidization of Wheat Bran Preparations: Improvement of Dispersion Stability by Structural Disintegration. Journal of Cereal Science, 64, 1-10. https://doi.org/10.1016/j.jcs.2015.04.002

[6] Pereyra-Castro, S.C., Alamilla-Beltrán, L., Villalobos-Castillejos, F., Porras Saavedra, J., Pérez-Pérez, V., Gutiérrez-López, G.F. and Jiménez-Aparicio, A.R. (2018) Microfluidization and Atomization Pressure during Microencapsulation Process: Microstructure, Hygroscopicity, Dissolution and Flow Properties. LWT-Food Science and Technology, 96, 378-385. https://doi.org/10.1016/j.lwt.2018.05.042

[7] Revathi, R., Chandran, D., Shin, L.H. and Manickam, S. (2018) Optimization of Palm Oil in Water Nano-Emulsion with Curcumin Using Microfluidizer and Response Surface Methodology. LWT_Food Science and Technology, 96, 58-65. https://doi.org/10.1016/j.lwt.2018.05.022 
[8] García-Márquez, E., Higuera-Ciapara, I. and Espinosa-Andrews, H. (2017) Design of Fish Oil-in-Water Nanoemulsion by Microfluidization. Innovative Food Science and Emerging Technologies, 40, 87-91.

[9] Koo, C.K.W., Chung, C., Ogren, T., Mutilangi, W. and McClements, D.J. (2017) Extending Protein Functionality: Microfluidization of Heat Denatured Whey Protein Fibrils. Journal of Food Engineering, 223, 189-196. https://doi.org/10.1016/j.jfoodeng.2017.10.020

[10] Oboroceanu, D., Wang, L., Kroes-Nijboer, A., Brodkorb, A., Venema, P., Magner, E. and Auty, M.A.E. (2011) The Effect of High Pressure Microfluidization on the Structure and Length Distribution of Whey Protein Fibrils. International Dairy Journal, 21, 823-830. https://doi.org/10.1016/j.idairyj.2011.03.015

[11] Demirkesen, I., Vilgis, T.A. and Mert, B. (2018) Effect of Microfluidization on the Microstructure and Physical Properties of a Novel Yoghurt Formulation. Journal of Food Engineering, 237, 69-77. https://doi.org/10.1016/j.jfoodeng.2018.05.025

[12] Iordache, M. and Jelen, P. (2003) High Pressure Microfluidization Treatment of Heat Denatured Whey Proteins for Improved Functionality. Innovative Food Science and Emerging Technologies, 4, 367-376. https://doi.org/10.1016/S1466-8564(03)00061-4

[13] Ciron, C.I.E., Gee, V.L., Kelly, A.L. and Auty, M.A.E. (2011) Effect of Microfluidization of Heat-Treated Milk on Rheology and Sensory Properties of Reduced Fat Yoghurt. Food Hydrocolloids, 25, 1470-1476. https://doi.org/10.1016/j.foodhyd.2011.02.012

[14] Lemay, A., Paquin, P. and Lacroix, C. (1994) Influence of Microfluidization of Milk on Cheddar Cheese Composition, Color, Texture, and Yield. Journal of Dairy Science, 77, 2870-2879. https://doi.org/10.3168/jds.S0022-0302(94)77227-1

[15] Chen, L., Chen, J.-S., Yu, L. and Wu, K.-G. (2016) Improved Emulsifying Capabilities of Hydrolysates of Soy Protein Isolate Pretreated with High Pressure Microfluidization. LWT-Food Science and Technology, 69, 1-8. https://doi.org/10.1016/j.lwt.2016.01.030

[16] Shen, L. and Tang, C.-H. (2012) Microfluidization as a Potential Technique to Modify Surface Properties of Soy Protein Isolate. Food Research International, 48, 108-118. https://doi.org/10.1016/j.foodres.2012.03.006

[17] Chen, J.-L., Gao, D.-X., Yang, L.-T. and Gao, Y.-X. (2013) Effect of Microfluidization Process on the Functional Properties of Insoluble Dietary Fiber. Food Research International, 54, 1821-1827. https://doi.org/10.1016/j.foodres.2013.09.025

[18] Karacam, C.H., Sahin, S. and Oztop, M.H. (2015) Effect of High Pressure Homogenization (Microfluidization) on the Quality of Ottoman Strawberry (F. Ananassa) Juice. LWT-Food Science and Technology, 64, 932-937. https://doi.org/10.1016/j.lwt.2015.06.064

[19] Mert, B. (2012) Using High Pressure Microfluidization to Improve Physical Properties and Lycopene Content of Ketchup Type Products. Journal of Food Engineering, 109, 579-587. https://doi.org/10.1016/j.jfoodeng.2011.10.021

[20] Huang, X.-Q., Tu, Z.-C., Jiang, Y., Xiao, H., Zhang, Q.-T. and Wang, H. (2012) Dynamic High Pressure Microfluidization-Assisted Extraction and Antioxidant Activities of Lentinan. International Journal of Biological Macromolecules, 51, 926-932. https://doi.org/10.1016/j.ijbiomac.2012.07.018

[21] Huang, X.-Q., Tu, Z.-C., Xiao, H., Li, Z., Zhang, Q.-T., Wang, H., Hu, Y.-M. and Zhang, L. (2013) Dynamic High Pressure Microfluidization-Assisted Extraction and Antioxidant Activities of Sweet Potato (Ipomoea batatas L.) Leaves flavonoid. Food 
and Bioproducts Processing, 91, 1-6. https://doi.org/10.1016/j.fbp.2012.07.006

[22] Norton, T. and Sun, D.-W. (2008) Recent Advances in the Use of High Pressure as an Effective Processing Technique in the Food Industry. Food and Bioprocess Technology, 1, 2-34. https://doi.org/10.1007/s11947-007-0007-0

[23] Tomasula, P.M. and Kozempel, M.F. (2004) Flow Characteristics of a Pilot-Scale High Temperature, Short Time Pasteurizer. Journal of Dairy Science, 87, 2761-2768.

[24] Van Boekel, M.J.S. (1998) Effect of Heating on Maillard Reaction in Milk. Food Chemistry, 62, 403-414. https://doi.org/10.1016/S0308-8146(98)00075-2

[25] Bucci, A.J., Van Hekken, D.L., Tunick, M.H., Renye, J.A. and Tomasula, P.M. (2017) The Effects of Microfluidization on the Physical, Microbial, Chemical, and Coagulation Properties of Milk. Journal of Dairy Science, 101, 6990-7001. https://doi.org/10.3168/jds.2017-13907

[26] Styles, M.F., Hoover, D.G. and Farkas, D.F. (1991) Response of Listeria Monocytogenes and Vibrio Parahaemolyticus to High Hydrostatic Pressure. Journal of Food Science, 56, 1404-1407. https://doi.org/10.1111/j.1365-2621.1991.tb04784.x

[27] Erkmen, O. and Karataş, Ş. (1997) Effect of High Hydrostatic Pressure on Staphylococcus aureus in Milk. Journal of Food Engineering, 33, 257-262.

[28] Patterson, M.F. (2005) Microbiology of Pressure-Treated Foods. Journal of Applied Microbiology, 98, 1400-1409.

[29] Rastogi, N.K., Raghavarao, K.S.M.S., Balasubramaniam, V.M., Niranjan, K. and Knorr, D. (2007) Opportunities and Challenges in High Pressure Processing of Foods. Critical Reviews in Food Science and Nutrition, 47, 69-112. https://doi.org/10.1080/10408390600626420

[30] Morton, J.D., Lee, H.Y.-Y., Grant Pearson, R. and Bickerstaffe, R. (2018) The Physical and Biochemical Effects of Pre-Rigor High Pressure Processing of Beef. Meat Science, 143, 129-136. https://doi.org/10.1016/j.meatsci.2018.04.021

[31] Zhang, H.-J., Pan, J. and Wu, Z.-Y. (2018) Investigation of the Effects of High Pressure Processing on the Process of Rigor in Pork. Meat Science, 145, 455-460. https://doi.org/10.1016/j.meatsci.2018.07.013

[32] Wang, H., Zhu, S.-M., Ramaswamy, H.S., Hu, F.-F. and Yu, Y. (2018) Effect of High Pressure Processing on Rancidity of Brown Rice during Storage. LWT-Food Science and Technology, 93, 405-411. https://doi.org/10.1016/j.lwt.2018.03.042

[33] Kim, S., Yang, S.Y., Chun, H.H. and Song, K.B. (2018) High Hydrostatic Pressure Processing for the Preparation of Buckwheat and Tapioca Starch Films. Food Hydrocolloids, 81, 71-76. https://doi.org/10.1016/j.foodhyd.2018.02.039

[34] Li, J., Zhao, F., Liu, H., Li, R., Wang, Y. and Liao, X. (2016) Fermented Minced Pepper by High Pressure Processing, High Pressure Processing with Mild Temperature and Thermal Pasteurization. Innovative Food Science and Emerging Technologies, 36, 34-41. https://doi.org/10.1016/j.ifset.2016.05.012

[35] Ribeiro, A.T., Elias, M., Teixeira, B.T., Pires, C., Duarte, R., Saraiva, J.A.S. and Mendes, R. (2018) Effects of High Pressure Processing on the Physical Properties of Fish Ham Prepared with Farmed Meagre (Argyrosomus regius) with Reduced Use of Microbial Transglutaminase. LWT-Food Science and Technology, 96, 296-306. https://doi.org/10.1016/j.lwt.2018.05.044

[36] Yuan, B., Danao, M.-G.C., Lu, M., Weier, S.A., Stratton, J.E. and Weller, C.L. (2018) High Pressure Processing (HPP) of Aronia Berry Puree: Pilot Scale Processing and a Shelf-Life Study. Innovative Food Science \& Emerging Technologies, 47, 241-248. 
https://doi.org/10.1016/j.ifset.2018.03.006

[37] Barcenilla, B., Román, L., Martínez, C., Martínez, M.M. and Gómez, M. (2016) Effect of High Pressure Processing on Batters and Cakes Properties. Innovative Food Science \& Emerging Technologies, 33, 94-99.

https://doi.org/10.1016/j.ifset.2015.11.011 